\title{
Webinar Socialization of Presidential Regulations Related to Digital Transformation and Strengthening Economic Foundations in Digitalization Era
}

\author{
Muammar Khaddafi, Mohd.Heikal, Falahuddin, Ichsan, Fuadi, Dammanhur, Rico \\ Nur Ilham, Ahmad Fauzul Hakim Hasibuan, Munandar, Chalirafi \\ Faculty of Economics and Business, Universitas Malikussaleh \\ E-mail: khaddafi@unimal.ac.id
}

\begin{abstract}
The Industrial Revolution is indeed familiar, Indonesia has known that the 4.0 industrial revolution has existed since 2011 but has been implemented by the Indonesian government since 2019 . Currently, Indonesia in terms of its economy often associates it with the Industrial Revolution. The Industrial Revolution is a change that occurs rapidly in the implementation of the production process or the way of making or increasing the use value of an item that originally used human power (traditional) to use machine tools (modern). The purpose of this community service is to help the community in implementing, being able to implement digitalization in everyday life and being able to develop it. People really need to know how important technology is in today's era. This activity is designed for 1 day starting with the socialization of presidential regulations on digital transformation, how to strengthen the economic foundation in the digitalization era and consumer behavior towards the digitalization era. The preparation for the socialization which was held through this webinar was preceded by coordination and communication with the Governor of the Riau Islands, the leadership of Bank Indonesia and the Head of the Doctoral Program in Human Resource Management at the University of Batam. The results of this activity are in line with what is expected, namely the activities carried out can help the community in preparing themselves and developing themselves in order to compete in the era of digitalization transformation. how to strengthen the economic foundation in the digitalization era and consumer behavior towards the digitalization era. The preparation for the socialization which was held through this webinar was preceded by coordination and communication with the Governor of the Riau Islands, the leadership of Bank Indonesia and the Head of the Doctoral Program in Human Resource Management at the University of Batam. The results of this activity are in line with what is expected, namely the activities carried out can help the community in preparing themselves and developing themselves in order to compete in the era of digitalization transformation. how to strengthen the economic foundation in the digitalization era and consumer behavior towards the digitalization era. The preparation for the socialization which was held through this webinar was preceded by coordination and communication with the Governor of the Riau Islands, the leadership of Bank Indonesia and the Head of the Doctoral Program in Human Resource Management at the University of Batam. The results of this activity are in line with what is expected, namely the activities carried out can help the community in preparing themselves and developing themselves in order to compete in the era of digitalization transformation.
\end{abstract}

Keywords: Digital Transformation, Consumer Behavior Patterns, Community Empowerment, Service

\section{INTRODUCTION}

Throughout the last decade, we have seen how big the impact of technological advances on changes in the way people move in various sectors of life, which we can call digital transformation. 
The effects of this digital transformation have also penetrated various sectors in business such as changing the way we work, communicate, and also change consumer behavior patterns (Aral et al. 2013; McDonald and Russel-Jones 2012). Digital technology facilitates the desire of various individuals to be able to connect the physical world with the digital world (Henfridsson et al. 2014). In the end, various business sectors experienced drastic changes in the rapidly changing demand from consumers.

Digital transformation is a change that utilizes digital technology to redesign traditional processes so that they can be more efficient and effective. So, this concept is not only limited to using technology to replicate existing processes or services into digital form. President Joko Widodo gave 5 main tasks for the Ministry of Communication and Information (Kominfo) to boost digital transformation in Indonesia, namely preparing a digital transformation roadmap, integrating national data centers, preparing human resource needs and digital talent and preparing the necessary regulations. October 2021, the Ministry of Communication and Information (Kominfo) confirmed that it had conducted FDGs with other government ministries/agencies, including private companies, then in the fields of education, health, social, e-commerce and so on. So that this digital roadmap will be very comprehensive so that the development of digitalization between one field and another can be integrated. For the integration of the national data center, the government will prepare a special building in the early stages.

Data is the largest asset that has extraordinary economic value, where data that is correlated and organized will become information and then become knowledge and wisdom. In terms of regulation, the Ministry of Communication and Information is committed to facilitating licensing for business actors in order to support industrial development in various telecommunications and digitalization sectors. In addition, in terms of regulation, the Communication and Information Technology will adjust the rules in accordance with the development of information technology and global developments.In responding to the 4.0 revolution, Up Skilling and Reskilling are needed for workers and prospective workers. There is a need for synergy between industry, local government and universities in meeting the needs of the 4.0 industrial revolution era, namely automation and digitalization (Indrayani, 2021).

Thus, this webinar is held with the aim of helping the community to jointly assist the Government in implementing and developing digitalization transformation in Indonesia and can provide input on the response that should be given by the Government in dealing with these problems.

\section{METHOD}

The webinar which was conducted through a virtual zoom meeting which was attended by 300 participants from various regions consisting of lecturers, students and the general public from both government/BUMN or private institutions starting on October 8, 2021. This webinar presented 3 resource persons, namely the Governor of the Riau Islands, Leaders Bank Indonesia, Head of the Doctoral Program in Human Resource Management at the University of Batam.

Preparation for service activities includes deliberations with the Governor of the Riau Islands and the Chair of the Doctoral Program in Human Resource Management at the University of Batam for the implementation of service activities. The preparation of this webinar is coordinated directly with the implementation plan related to the socialization of presidential regulations regarding digital 


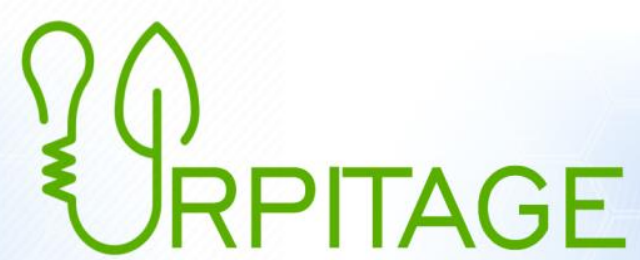

InTERnational REVIEW of PRACTICAL InNOVATION, TECHNOLOGy AND GREEN ENERgy

transformation in the digitalization era. To socialize the problems faced in this activity, structured activities are designed.

\section{RESULTS}

The problems faced by society today began with the development of technology 4.0 in Indonesia since 2019, namely (1) causing an increase in global competitiveness through cooperation and confederation of companies. It can be seen that products will no longer be made by a worker in the future, but by robots or programmers and it doesn't take a long time to process a product, so that it can make it easier for companies to accelerate product marketing, and for marketing, this change should be able to carry out a strategy positioning. Positioning strategy is a very important factor in increasing the strength of the company's market position. In addition, a positioning strategy is needed as a step in determining market segments for businesses, (2) In addition to the impact of the Industrial revolution 4. 0 is one of the main drivers of increasing company revenues, overcoming financial difficulties in business, and can increase the country's GDP growth and (3) The impact of the 4.0 Industrial revolution is to provide a platform for further innovation bases with developing technologies. Manufacturing systems and services can be further developed. For example, with the application of accounting bookkeeping, the more development of accounting bookkeeping technology, the more it can make it easier for business people to clean up their books, one bookkeeping that can make it easier for you is to use Harmony Accounting Services. 0 is to provide a platform for further innovation base with developing technology. Manufacturing systems and services can be further developed. For example, with the application of accounting bookkeeping, the more development of accounting bookkeeping technology, the more it can make it easier for business people to clean up their books, one bookkeeping that can make it easier for you is to use Harmony Accounting Services. 0 is to provide a platform for further innovation base with developing technology. Manufacturing systems and services can be further developed. For example, with the application of accounting bookkeeping, the more development of accounting bookkeeping technology, the more it can make it easier for business people to clean up their books, one bookkeeping that can make it easier for you is to use Harmony Accounting Services.

Figure 1. Webinar Documentation of Presidential Regulations Related to Digital Transformation and Strengthening Economic Foundations in the Era of Digitalization on Consumer Behavior Patterns

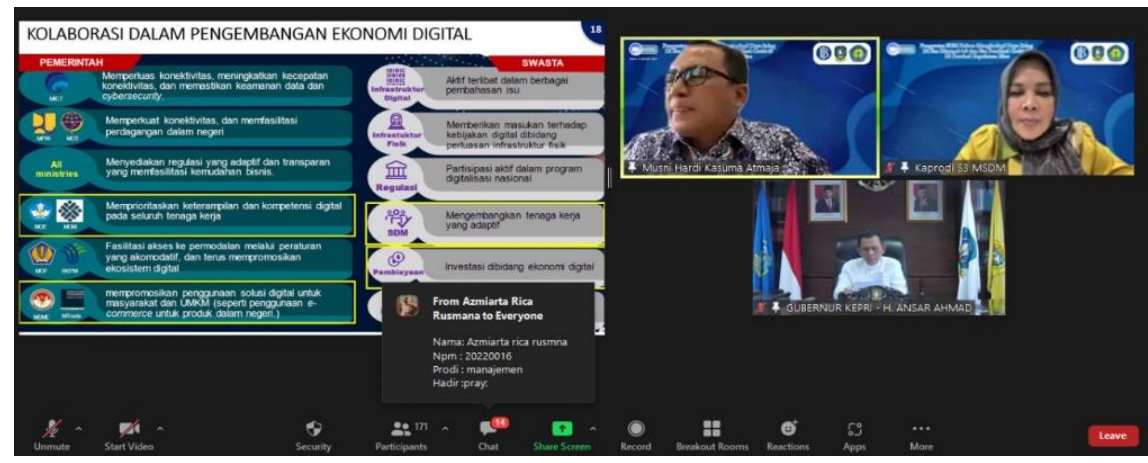

Figure 2. Implementation of the Presidential Regulation Webinar Regarding Digital Transformation and Strengthening Economic Foundations in the Era of Digitalization on Consumer Behavior Patterns 


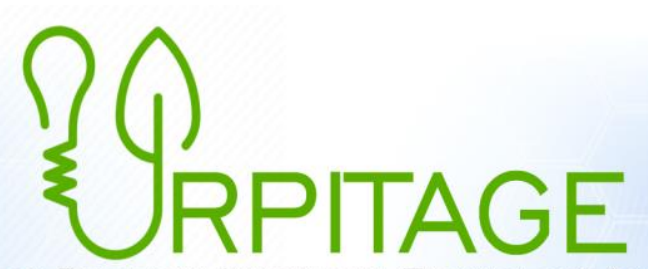

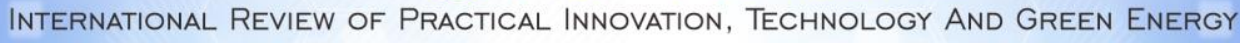

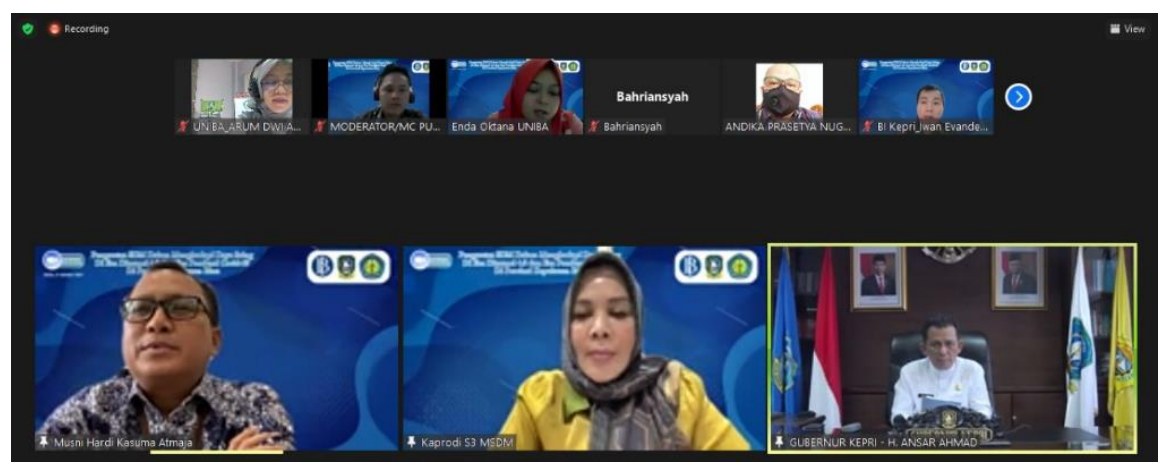

\section{REFERENCE}

Aral, S., Dellarocas, C., and Godes, D. (2013). Social Media and Business Transformation: A Framework for Research (24:1), pp. 3-13.

Basu Swastha Dharmmesta, T. Hani Handoko, 2000, Marketing Management "Analysis of consumer behavior". First edition, third printing. BPFEYogyakarta, Yogyakarta

Kaplan, B, Truex, DP, Wastell, D, Wood-Harper, AT \& DeGross, J. (2010). Information Systems Research: Relevant Theory and Informed Practice. Springer.

McDonald, MP, and Russell Jones, A. (2012). The Digital Edge - Exploiting Information and Technology for Business Advantage. Gartner eBooks

Westernman, G., Calmejane, C., Bonnet, D. (2011). Digital Transformation: A Roadmap for the Billion Dollar Organization. MIT Center for Digital Business, 1-68. 